\title{
RECONNAISSANCE AND SABOTAGE PLANS OF SPECIAL AGENCIES OF NAZI GERMANY IN KALMYKIA DURING THE GREAT PATRIOTIC WAR
}

\author{
Konstantin N. Maksimov \\ Kalmyk State University named after B. B. Gorodovikov, Elista, Russian Federation
}

\begin{abstract}
Introduction. On the basis of new resources, the article examines the actions of the Nazi agencies which inculcated sabotage groups of betrayers and experienced German agents on the Ju-290 of the Luftwaffe in 1943-1944 in the Kalmyk steppe. The main purpose of the German operations was to conduct reconnaissance and sabotage actions in the rear of the red army to cause the uprising of the population of Kalmykia. Methods and materials. Scientific, popular science publications that have appeared in recent years and documents introduced into scientific circulation cover only the general picture and fragmentary episodes of special operations of secret Luftwaffe units. The main source base of the article consists of unpublished documents identified by the author in the funds of the State Archives of the Russian Federation. These are documents about the results of the interrogations of some of the leaders of the fascist special services, certificates, reports, cases of various Soviet special services and officials addressed to the leaders of the highest party, state bodies, the NKVD of the USSR. These documents are devoted to the results of the fight against banditry in the country, with desertion, evasion of service. Analysis and results. The Abwehr group (Otto Verba's103 officers with the agent name - the doctor Doll) having the false information about the readiness of the rebels for uprising planned to raise a rebellion of the Kalmyk population. In this connection, the German special services planned a special operation under the code name Salzsee ('Salt lake'). In October 1943 and May 1944 the Germans using the newest Junkers landed prepared saboteurs groups of collaborators and experienced scouts in the central part of the Kalmyk steppe. Some of the crews of aircraft and saboteurs were destroyed by the chekists, captured scouts agreed to cooperate with the SMERSH and to participate in the radio game. As a result, due to the radio game Aryans held by the Soviet intelligence, the Abwehr group intentions had completely failed. The Germans lost two new Ju-290 aircrafts with crew members and experienced scouts. During the operation Dr. Doll secretly disappeared and after the war found himself in the Eastern part of Germany.

Key words: the Abwehr, Doctor Doll, Salzsee operation, reconnaissance and sabotage groups, Kalmyk steppe, NKVD of the USSR, SMERSH, radio game Aryans.

Citation. Maksimov K.N. Reconnaissance and Sabotage Plans of Special Agencies of Nazi Germany in Kalmykia During the Great Patriotic War. Vestnik Volgogradskogo gosudarstvennogo universiteta. Seriya 4, Istoriya. Regionovedenie. Mezhdunarodnye otnosheniya [Science Journal of Volgograd State University. History. Area Studies. International Relations], 2019, vol. 24, no. 1, pp. 109-122. (in Russian). DOI: https://doi.org/10.15688/ jvolsu4.2019.1.9
\end{abstract}

УДК 94(470.47).084.8

ББК ТЗ(2РОС.Калм)622-9

Дата поступления статьи: 28.04.18

Дата принятия статьи: 18.06 .18

\section{РАЗВЕДЫВАТЕЛЬНО-ДИВЕРСИОННЫЕ ПЛАНЫ СПЕЦСЛУЖБ ФАШИСТСКОЙ ГЕРМАНИИ В КАЛМЫКИИ В ГОДЫ ВЕЛИКОЙ ОТЕЧЕСТВЕННОЙ ВОЙНЫ}

\author{
Константин Николаевич Максимов \\ Калмыцкий государственный университет им. Б.Б. Городовикова, г. Элиста, Российская Федерация \\ Аннотация. В статье на основе новых источников рассматриваются действия фашистских спецслужб \\ по забрасыванию в 1943-1944 гг. в калмыцкую степь диверсионных отрядов из коллаборационистов и опыт-
}


ных немецких разведчиков на «Јu-290» секретных подразделений люфтваффе. Главными целями этих операций являлись разведывательно-диверсионные действия в тылу Красной армии, организация восстания населения Калмыкии. Абвер на основе ложной информации своего сотрудника из «Абвергруппы-103» зондерфюрера Отто Верба (агентурный псевдоним - доктор Долль) о якобы готовности к выступлению повстанцев планировал поднять восстание калмыцкого населения. С этой целью немецкие спецслужбы запланировали спецоперацию под кодовым названием «Salzsee» («Соленое озеро»). Немцы в октябре 1943 и мае 1944 г. на новейших «юнкерсах» десантировали в центральной части калмыцкой степи подготовленных диверсантов из коллаборационистов и опытных своих разведчиков. Часть из экипажей самолетов, диверсантов была уничтожена чекистами, а плененные разведчики согласились сотрудничать со СМЕРШем, участвовать в радиоигре. Замыслы абвера в результате радиоигры «Арийцы», проведенной советской разведкой, полностью завершились провалом. Немцы в нелегкое для них время потеряли два новейших «Јu-290» с членами экипажей и опытных разведчиков. Доктор Долль еще в ходе операции инкогнито исчез и после войны оказался в восточной части Германии.

Ключевые слова: абвер, доктор Долль, операция «Salzsee», разведдиверсионные группы, калмыцкая степь, НКВД СССР, СМЕРШ, радиоигра «Арийцы».

Цитирование. Максимов К. Н. Разведывательно-диверсионные планы спецслужб фашистской Германии в Калмыкии в годы Великой Отечественной войны // Вестник Волгоградского государственного университета. Серия 4, История. Регионоведение. Международные отношения. - 2018. - Т. 24, № 1. - С. 109-122. DOI: https://doi.org/10.15688/jvolsu4.2019.1.9

Введение. Накануне и в годы Великой Отечественной войны германские службы Управления разведки и контрразведки Верховного командования вермахта (Abwehr) активно использовали секретные подразделения люфтваффе для выполнения специальных заданий по заброске агентуры и диверсантов не только в приграничные и прифронтовые зоны, но и вглубь Советского Союза - центральную часть России, Среднюю Азию, Кавказ, Урал. Цель спецопераций подобного рода - сбор информации военного, оборонного, экономического и политического характера, проведение диверсий на промышленных объектах, железных дорогах, организация вооруженных банд и восстаний, подготовка аэродромов, секретных баз и мощных радиостанций. Несмотря на широкий размах в 1941-1944 гг. секретных операций люфтваффе и значительный охват регионов страны, эта тема остается малоисследованной как в целом, так и по отдельным регионам, а также операции крупных раведывательно-диверсионных отрядов врага, которые забрасывались в глубокий тыл СССР. Основная причина этого пробела в историографии войны заключалась в ограниченности доступа исследователей к засекреченным материалам фондов органов спецслужб СССР.

Методы и материалы. Появившиеся в последние годы научные, научно-популярные публикации и вводимые в научный оборот документы освещают лишь общую картину и фрагментарно отдельные эпизоды спецопераций секретных подразделений люфтваффе [3; $8 ; 10 ; 12 ; 27]$. К сожалению, многие из них недостаточно научно обоснованы, имеют фактические неточности, противоречия, и серьезным их недостатком является отсутствие указаний на исторические источники. Поэтому в статье ставится цель - на основе выявленных новых источников, в контексте общей проблемы борьбы советских спецслужб в годы войны с немецкими разведдиверсантами, забрасываемыми парашютистами вглубь страны, осветить, восполнить картину происходивших событий, связанных с десантированием фашистских двух крупных разведдиверсионных групп и ликвидацией их советскими спецслужбами осенью 1943 и летом 1944 г. в калмыцкой степи.

Основную источниковую базу статьи составили неопубликованные документы, выявленные автором в фонде № 9478 «Главное управление по борьбе с бандитизмом (ГУББ) НКВД - МВД СССР» (опись 1) Государственного архива Российской Федерации. В нем хранятся докладные о результатах допросов некоторых руководителей фашистских спецслужб, взятых в плен, справки, отчеты, записки, сводки, дела различных советских спецслужб и должностных лиц на имя руководителей высших партийных, государственных органов, НКВД СССР о состоянии и результатах борьбы с бандитизмом в стране, с дезертирством, 
уклонением от службы. Особо ценные сведения имеются по борьбе с вражескими разведывательно-диверсионными группами, парашютистами, заброшенными в глубокий тыл СССР, в том числе докладные на имя Л.П. Берии о приземлившихся немецких самолетах с разведдиверсантами в калмыцкой степи.

По теме статьи ценные сведения выявлены в документах, опубликованных в многотомных сборниках «Органы государственной безопасности СССР в Великой Отечественной войне», «Нюрнбергский процесс» и др. Учитывая серьезные пробелы в имеющихся публикациях по данной теме, автор статьи прежде всего опирался на документы официальных учреждений, спецслужб, подвергая их источниковедческому анализу. Это позволило на основе новых источников полнее осветить спецоперации, проведенные советскими спецслужбами в 1943-1944 гг. в калмыцкой степи.

Анализ. Задача организации подрывной деятельности и саботажа на территории противника, в том числе и Советского Союза, была возложена на второй отдел абвера (абвер II, начальник - полковник Лахузен), состоявший из 5 подотделов, разделявшихся на 15 самостоятельных рефератур. Второй отдел имел крупные учебные центры для подготовки диверсантов и агентов [3, с. 10]. Конрад Шломс, бывший управляющий делами института «Арбайтсгемайншафт Туркестан» («АТ»), на допросе подтвердил, что с ухудшением обстановки на Восточном фронте стало усиливаться влияние Главного управления полиции безопасности Германии (CC рейхсфюрер Г. Гиммлер), особенно Главного управления имперской безопасности (РСXА обергруппенфюрер СС Р. Гейдрих) [27, с. 273].

С января 1943 г. РСХА возглавил Э. Кальтенбруннер. В это же время в его 6-й отдел, имевший специальные школы, которые готовили агентуру для заброски в тыл СССР, был переведен гауптштурмфюрер СС Райнер Ольцша, врач, известный ученый, свободно владеющий французским и русским языками. До перевода, с октября 1941 г. в составе санитарного батальона СС он занимался обработкой и изучением захваченных медицинских документов на территории Советского Союза. Все это он изложил сотрудникам СМЕРШа в ходе следствия в октябре 1945 года. Результаты следствия по его делу в ноябре были доложены руководству НКВД СССР.

В докладной о ходе следствия по делу Ольцша на имя Л.П. Берии и В.Н. Меркулова указывалось, что в последующем он служил начальником Восточного реферата при группе «6-С», которая занималась разведывательной деятельностью в СССР, Турции, Иране, Афганистане, Индии, Китае и Японии. В эту же группу «6-С» входила служба «Унтернемен Цеппелин», основная деятельность которой была направлена на политическое разложение Советского Союза. Эта служба, занимаясь разработкой планов, разведывательной работой, главное внимание уделяла проведению диверсий в тылу СССР, сбору сведений о военно-политическом положении Советского Союза, состоянии его оборонной промышленности, политико-моральном состоянии населения. Служба «Цеппелин» также занималась вербовкой и обучением агентуры и диверсантов из числа военнопленных Красной армии, определяла приемы и методы связи с закардонной агентурой, организовывала переброску в тыл СССР диверсионных групп для шпионско-разведывательной деятельности. Служба «Цеппелин» имела учебный лагерь в Зандберге (Верхняя Силезия) по подготовке диверсантов и заброске их в СССР [10, л. 86-88].

На помощь к этим фашистским спецслужбам были подключены националистические организации (комитеты, штабы, центры, бюро), созданные при имперском министерстве по делам оккупированных восточных областей (восточном министерстве - Остминистериум) во главе с рейхслейтером А. Розенбергом. Такими организациями, возглавляемыми белоэмигрантами, являлись «Туркестанский комитет», «Волго-татарский комитет» (Идел-Урал), «Крымский центр», «Азербайджанский штаб», «Северо-Кавказский штаб», «Армянский штаб», «Грузинский штаб». Их агентурным обслуживанием занимался организованный по распоряжению Гиммлера в сентябре 1943 г. институт «Арбайтсгемайншафт Туркестан» под руководством гауптштурмфюрера СС Ольцша Райнера. По признанию на допросе Р. Ольцша руководство института планировало в случае оккупа- 
ции Средней Азии образовать «Большой Туркестан» в составе Казахской, Узбекской, Таджикской, Киргизской советских республик. В связи с этими планами лидеры «Туркестанского комитета» активизировали деятельность по привлечению из числа военнопленных «туркестанцев» в «добровольческие легионы» [7, л. $88 ; 27$, с. 276-277].

В соответствии с данными стратегическими целями Верховное германское командование (OKW) ставило задачу соединениям группы армий «В» (командующий - генералполковник М. фон Вейхс), действующим на юго-восточном внешнем оборонительном обводе Сталинграда, закрыть брешь между флангами групп армий «A» и «B», захватить Астрахань, низовье Волги и перерезать снабжение Сталинграда, ударить во фланг советским войскам, сражающимся в Сталинграде, подготовить плацдарм для дальнейшего продвижения за Волгу, на Кавказ, в Среднюю Азию и Казахстан. Таким плацдармом планировалось сделать калмыцкую степь, где возможно было подготовить площадку для приема тяжелых самолетов, разместить мощную радиостанцию. Поэтому не случайно в состав 16-й мотодивизии (мд) (командир - генераллейтенант 3. Хейнрици), выдвинутой в августе 1942 г. в калмыцкую степь на астраханское направление, были включены три туркестанских батальона: 450-й (командир - майор Берген), 782-й (командир - капитан Хайнрих Хайзе) и 811-й (командир - майор Курт), личный состав которых состоял из 2656 «туркестанцев» (узбеки, казахи, киргизы, туркмены, таджики и каракалпаки) и 90 немцев (командный состав). 16-я мд вступила в Калмыкию 25 августа 1942 г. на смену частям (111-й и 370-й пехотным дивизиям) 52-го армейского корпуса генерала пехоты Отта, оккупировавшим часть территории Калмыкии 12 августа 1942 г. [11, с. 210-212; 19, с. 366-367].

В попытке реализации этой стратегической цели проявили заинтересованность абвер и вермахт. Почти одновременно с 16-й мд в Калмыкию был направлен из «абвергруппы-103» (командир - майор А. Иохаим), дислоцированной в станице Николаевской (в 6 км от г. Пятигорска), спецотряд во главе с зондерфюрером Отто Рудольфовичем Вербом (агентурный псевдоним - доктор Долль, позывной его ра- диостанции - «Kranich»- «Журавль») и его помощником, белоэмигрантом Н.А. Биданоковым (он же Пурбий Алхазович, псевдоним - Шамиль). «Абвергруппа-103» подчинялась «абверкоманде-101» разведывательного штаба «Валли-1» (руководитель - майор Баун), созданного в мае 1941 г. для руководства всеми разведорганами абвера против СССР [15, с. 425].

Однако группу доктора Долля, подготовленную в Варшаве резидентом немецкой разведки («абвергруппы-103») Фоулидисом (псвевдоним - Локкарт), заботили не столько стратегические цели и Калмыкия, а сколько более важный объект - Сталинградский фронт. Группе Долля было поставлено задание, используя близлежащий район его дислокации к Сталинграду Калмыкию, собирать сведения о коммуникации, численности войск в прифронтовой полосе, об их вооружении, о наличии резервов и транспорта, местонахождении штабов, системе противотанковой обороны и т. д. В директиве НКВД СССР № 544 от 3 декабря 1942 г. «О мерах по розыску и аресту агентов авбергруппы-103» указывалось, что следует иметь в виду - «привлекаемая агентура вербуется из местных жителей и военнопленных - бывших военнослужащих Красной армии» [25, с. 116-117].

В докладной записке отдела НКВД СССР по борьбе с бандитизмом и дезертирством, подписанной 30 августа 1944 г. начальником отдела, комиссаром госбезопасности 3-го ранга А. Леонтьевым, Отто Верб почему-то назван «белоэмигрантом, наместником Калмыкии». Между тем Отто (Отмар) Рудольфович Верб являлся австрийским офицером, а затем профессиональным разведчиком, еще в годы Гражданской войны был представителем немецкого командования на стороне Петлюры в чине украинского офицера. В последующем работал предпринимателем, архитектором, служил сотрудником в германском консульстве в Одессе. В начале августа 1942 г. был направлен по рекомендации подполковника разведотдела 1-й танковой армии барона фон Фрайтага-Лорингхофена с 16-й мотодивизией из 3-го танкового корпуса 1-й танковой армии генералполковника Э. фон Клейста в калмыцкую степь $[6$, л. 55-56; 22, с. 9, 53].

По линии вермахта в штаб 16-й мд были включены ротмистр, профессор-исто- 
рик барон фон Рихтгофен (крупный монголовед, специалист по Калмыкии, даже сочинял стихи на калмыцкие сюжеты на немецком и калмыцком языках) и офицер генштаба обер-лейтенант доктор Хольтерманн. В период активных боевых действий 16-й мд в астраханском направлении в Элисту прибыла особая зондеркоманда СД-11a («Зондеркоманда Астрахань», командир гауптштурмфюрер Маурер), созданная оперативной специальной группой «D» полиции безопасности (ЗиПо), руководимой штурмбанфюрером СС В. Куреком и дислоцированной на Юге России и Кавказе. Ее основной целью являлась подготовка к пропагандистской работе в Астрахани в связи с предполагаемым ее захватом $[16$, c. 503,$504 ; 18$, c. $249 ; 22$, c. 44$]$.

В формировании и подготовке, присоединении туркестанских батальонов к составу 16-й мотодивизии активную роль проявили не только «Унтернемен Цеппелин» и «Туркестанский комитет», но и службы абвера. В это же время активизировал деятельность «Калмыцкий национальный комитет» (руководитель - белоэмигрант Ш.Х. Балинов), поддерживавший тесную связь с «Туркестанским комитетом» и работавший под руководством указанных спецслужб и восточного министерства. Лидеры «Калмыцкого национального комитета» («Kalmukischen Aushoss») надеялись с помощью немцев вернуться в Калмыкию и создать под протекторатом Германии национальное государственное образование - Калмыцкую область в составе планировавшегося восточным министерством рейхскомиссариата «Кавказ». В случае оккупации Кавказа А. Розенберг, по свидетельству Райнера Ольцша, планировал назначить рейхскомиссаром немца Шикеданца [15, c. 552,$553 ; 27$, c. $282-283]$.

Немецкие спецслужбы и комитет Ш. Балинова особо возлагали надежды на создание военных калмыцких формирований, способных бороться с партизанами, частями Красной армии в Калмыкии. Доктору Доллю совместно с местной немецкой администрацией удалось к концу 1942 г. на базе сельских охранных и полицейских отрядов сформировать два эскадрона (1/66 и 2/66) численностью до 200-250 человек. Однако фашисты не смогли реализовать свои замыслы по формированию на территории Калмыкии боеспособного подразделения из местного населения. В записке НКВД СССР в ГКО от 18 марта 1943 г., подписанной заместителем наркома внутренних дел В.Н. Меркуловым, отмечалось, что «германское командование, играя на националистических чувствах, пыталось (выделено автором. $-K . M$.) сформировать в Калмыкии добровольческий калмыцкий кавалерийский корпус» и «оккупанты намерены (выделено автором. $-K$. .) были сформировать “правительство Калмыкии”» [17, с. 304].

После освобождения Калмыкии от немецких оккупантов, лишь в начале 1943 г., уже за ее пределами (на территории Орджоникидзевского - ныне Ставропольского - края) из незначительного количества граждан республики, служивших фашистам в период оккупации и ушедших при отступлении вместе с ними, было создано подразделение, получившее название «Калмыцкое воинское подразделение доктора Долля», в составе 6 эскадронов [10, с. 58], численностью до 1,5 тыс. человек. По свидетельству бывших бойцов эскадронов на судебном процессе, немцы «в пропагандистских и провокационных целях» назвали это подразделение «кавалерийским корпусом» [21]. Немецкий историк Б. Мюллер-Гиллебранд, учитывая количественный состав подразделений, относит его к «восточному войску» - типу батальонного звена. Что касается национального состава «корпуса», вполне подтверждается свидетельство А. Некрича о том, что «после ухода из Калмыкии в “корпус" влились разнородные, враждебные советской власти элементы, и они не обязательно были калмыки» [13, c. $390 ; 14$, c. $257 ; 18]$.

В отчетах Управлению «Абвер-Заграница» в начале 1944 г. доктор Долль указывал общую цифру количественного состава «корпуса» вместе с цивильным (гражданским) населением - 5 тыс. человек. Эта цифра, введенная без источниковедческого анализа в научный оборот известным немецким историком Й. Хоффманном, в отечественной историографии кочует из одного произведения в другое как показатель общей численности калмыков, воевавших на стороне немцев. Между тем по свидетельству бывшего начальника штаба «корпуса» Д.А. Арбакова в 
нем насчитывалось не более 2 тыс. бойцов и около 3 тыс. беженцев (в основном семьи бывших служителей оккупационной администрации). По свидетельству того же Хоффманна максимальная численность 24 эскадронов калмыцкого легиона составляла 3600 чел. в июне 1944 г., накануне его разгрома под Люблиным и потери его значения как боевой единицы [2, с. 78; 22, с. 115, 143, 193-194].

Немцам в калмыцкой степи не удалось реализовать свои планы, поскольку 16-й мд в связи с окружением в Сталинграде 6-й полевой армии Ф. Паулюса и некоторых частей 4-й танковой армии Г. Гота пришлось под натиском 28-й армии поспешно отступить из Калмыкии. Немцы, покидая оккупированные улусы республики, все же вынашивали план организовать там «третью силу» и поднять восстание местного населения. Для такого оптимистического замысла фашистов, видимо, послужило сообщение доктора Долля в VI управление (СД) РСХА о том, что им якобы сформированы и находятся в калмыцкой степи 5 эскадронов $(9,10,11,15$ и 16-й), готовых развернуть антисоветское движение партизанскими методами. Кроме того, Долль заверял руководство спецслужб о якобы имеющихся возможностях подготовить еще 36 эскадронов для переброски на помощь мифическим повстанцам в калмыцкой степи.

Эта информация и предложение Долля были не более чем авантюризм с целью показа абверу «масштабов и результатов» своей деятельности. Ложные сведения Долля, отраженные в его официальных отчетах, которые отложились в архивах абвера, немецкий историк Й. Хоффманн использовал в своем труде [22, с. 41-42; 26, с. 512], не подвергнув источниковедческому анализу. Между тем в различных официальных справках, докладных записках НКВД и других спецслужб СССР о положении в Калмыцкой АССР, калмыцкой степи в годы войны и после депортации калмыков, составленных в разное время на имя руководства ГКО, ЦК ВКП(б), СНК СССР, не имеется никаких упоминаний и сведений о каких-либо эскадронах, оставленных немцами в калмыцкой степи.

Доктор Долль, предлагая абверу авантюристическую идею превратить Калмыкию в площадку «третьей силы», поднять восстание ее населения, по всей вероятности, сам не мог предположить, что руководство фашистской разведки примет ее всерьез. «Цеппелин», поверив ложным докладам Долля, решил помочь мифическим повстанцам Калмыкии. Была запланирована операция под кодовым названием «Salzsee» («Соленое озеро»), состоявшая из нескольких циклов. К тому же после провала молниеносной войны эта операция вполне вписывалась в общий план вермахта и спецслужб Германии по развертыванию широкомасштабной разведывательно-диверсионной деятельности на территории СССР. По периодизации историка А.С. Чайковского «тайной войны» нацистской Германии, 1943-1944 гг. относятся к третьему периоду, когда ее спецслужбы попытались при помощи диверсий и организации бандитских, повстанческих движений дестабилизировать советский тыл [24, с. 12-13].

Действительно, по неполным данным только с июня и до середины декабря 1943 г. немецкие спецслужбы забросили в некоторые области (Смоленская, Ленинградская, Сталинградская, Ярославская, Ивановская, Рязанская, Орловская, Калининская, Черкесская автономная область и др.), края (Краснодарский, Ставропольский) и республики (Туркменская, Узбекская, Казахская, Азербайджанская, Грузинская ССР, Кабардино-Балкарская, Дагестанская, Чечено-Ингушская, СевероОсетинская АССР) 48 разведдиверсионных групп. Всего в 1943 г., по данным отдела НКВД СССР по борьбе с бандитизмом и дезертирством, были арестованы 1036 вражеских парашютистов, диверсантов и агентов. Только в Казахскую ССР 21, 23, 24, 28 августа 1943 г. немцы десантировали 4 группы диверсантов с целью распространения газеты «Новый Туркестан», листовок, корана; сбора сведений о настроении населения, дислокации и состоянии воинских частей, оборонной промышленности, о движении воинских эшелонов; совершения диверсии на нефтепромыслах, заводах. Bсе парашютисты четырех групп были арестованы, и контрразведчики СМЕРШа организовали радиоигру с противником под условным названием «Тростники» $[5$, л. 2-13, 15, 18, 22-22 об., 28, 28 об.; 6, л. 53-54, 84; 7, л. 104].

Первым этапом запланированной немцами операции «Salzsee» на 1943 г. в калмыцкой 
степи стала «Римская цифра два». На этом этапе, согласно предложенному Доллем плану, намечалось объединить и вооружить якобы действовавшие в калмыцких степях разрозненные повстанческие банды и с их помощью спровоцировать восстание местного населения. При этом предполагалось перебросить воздушным путем на помощь повстанцам якобы сформированное доктором Доллем калмыцкое воинское подразделение в составе «36 эскадронов». Между тем к концу сентября 1943 г., по данным отдела НКВД СССР по борьбе с бандитизмом и дезертирством, на территории Калмыцкой АССР были ликвидированы 19 бандгрупп из 23, оставались лишь 4 группы в количестве 33 человек, а к декабрю - всего 17 человек. Никаких мифических оставленных эскадронов в калмыцкой степи не существовало в 1943-1944 годах. По имеющимся данным в соседних Калмыкии Ростовской, Сталинградской областях и Ставропольском крае в 1943 г. были ликвидированы 205; 45 и 134 бандгрупп соответственно. На территории СССР в 1943 г. были уничтожены 3875 бандгрупп с участием 30312 человек [6, л. 53-54; 20, л. 2-2 об., 29].

Немецкие спецслужбы, не располагая, по всей вероятности, достаточными сведениями о положении в калмыцкой степи, всецело поверили и положились на доктора Долля, считавшегося, по его «полным» отчетам в абвер, эффективным разведчиком и знатоком калмыков. Подготовку первой фазы под кодовым названием «Римская цифра два» операции «Salzsee» немцы начали с выбросом 1 октября 1943 г. пяти парашютистов из двухмоторного пикирующего бомбардировщика, вылетевшего из г. Николаева, в 20-25 км юго-восточнее поселка Яшкуль Черноземельского улусного центра [5, л. 17]. Почти одновременно, 19 октября 1943 г., немцы забросили 7 парашютистов в 40 км от Сарепты с целью проведения диверсий в Сталинграде [5, л. 6].

В книге Д.М. Дегтева и Д.В. Зубова неверно указано, что разведгруппа 1 октября 1943 г. десантировалась «в районе железнодорожной станции Яшкуль» [3, с. 151]. В Калмыкии никогда не было и не имеется до сих пор «железнодорожной станции Яшкуль», а поселок Яшкуль находится от железных дорог не менее чем в 200-250 км на всех направлениях.
Только 25 октября начальник Черноземельского улусного отделения НКГБ Калмыцкой АССР получил информацию от местных жителей о том, что бежавшие с отступившими немцами Сога Эренценов и Харцха Эрдниев, их односельчане, открыто появились здесь. 27 октября оперативная группа НКВД КАССР, организованная для поимки парашютистов, обнаружила их в районе Аким-Пески Черноземельского улуса. В результате боевой операции были задержаны 7 бандитов, в их числе парашютист Ворона-Мартынюк и 6 местных жителей, помогавших агентам скрываться.

У Вороны-Мартынюка была изъята портативная немецкая рация, шифродокументы, револьвер системы Нагана, пистолет ТТ, различные справки. При допросе выяснилось, что Ворона-Мартынюк (настоящая фамилия Мартыненко) Александр Данилович, 1907 года рождения, житель города Киева, псевдоним Титов. По призыву немцев поступил в школу радистов и получил специальность радиста, окончив разведшколу при штабе немецкой армии 28-527 в Запорожье. Из 50 выпускников этой школы он попал в группу Огдонова Басанга (псевдоним - Хасан), жителя села Олинга (Зюнгаровского сельского совета Черноземельского улуса Калмыцкой АССР), который уклонился от призыва в Красную армию и ушел в степь к бандитам, в период оккупации служил у немцев и вместе с ними бежал, находился в калмыцком подразделении доктора Долля [5, л. 17].

Титов на допросе показал, что группа в составе пяти парашютистов (старший Б. Огдонов, Сога Эренценов - псевдоним Гриша, Харцха Эрдниев - Миша, Мууда Халгаев Саша, Ворона-Мартынюк) вылетела 1 октября 1943 г. из г. Николаева и была выброшена в 25 км юго-восточнее поселка Яшкуль. При боестолкновении 27 октября раненому Огдонову, Эрдниеву и Эренценову удалось скрыться. Направленный на их розыск агент-маршрутник НКВД КАССР «Эрдниев» 29 октября встретился с Огдоновым и Эренценовым в местности Нурин-Хак Кетченеровского улуса. Агент-маршрутник выяснил, что ни Огдонов, ни Эренценов не знали о местонахождении парашютистов Эрдниева и Халгаева и об аресте радиста. Агент-маршрутник в своем отчете 
подтвердил информацию о полученных Огдоновым ранениях в плечо и шею [4, л. 124-125].

Донесение агента-маршрутника от 3 ноября о том, что парашютист X. Эрдниев был склонен сдаться, подтвердилось. 8 ноября 1943 г. Х. Эрдниев явился в органы НКВД КАССР с повинной. Однако позднее его раскаяние не спасло от наказания за дезертирство из армии и службу немцам. 9 ноября оперативная группа НКВД КАССР обнаружила в 18 км юго-восточнее Яшкуля труп и документы разбившегося парашютиста М. Халгаева. Несмотря на продолжавшиеся поиски Огдонова и Эренценова, вскоре затерялись их следы в обширных калмыцких степях. Только в 1945 г. оба были убиты - С. Эренценов в мае, Б. Огдонов в октябре [1, с. $170 ; 5$, л. 17 об.].

В ходе допроса было установлено, что радист Ворона-Мартынюк до своего ареста (27 октября) успел отправить 4 кодограммы, тексты которых были подготовлены Хасаном, о благополучном приземлении, об отсутствии военных частей и движений транспорта с вооружением на территории Калмыцкой АССР, а также о трудностях выяснения сведений о наличии бандформирований, способных к выступлению. Действительно, уже в январе 1943 г. на территории Калмыкии полностью были завершены боевые действия, и оккупанты изгнаны. В этот период десантирования фашистских агентов в калмыцких степях не было ни воинских частей, ни гарнизонов Красной армии, ни бандформирований. Советских оперативников заинтересовало сообщение Хасана в службу «Валли-1» о том, что группа его сможет принять большой десант [1, с. 165]. Эта информация насторожила спецслужбы СССР тем, что основной задачей группы Огдонова было объединить бандгруппы и начать военные действия в советском тылу, с прибытием крупного десанта развернуть повстанческое движение.

Через некоторое время Б. Огдонов, установив отсутствие бандформирований в калмыцкой степи, не найдя поддержки у населения и поняв свою обреченность, решил подтвердить ложные донесения доктора Долля о готовности «калмыцких повстанцев». Он доложил своему руководству (представителю «Валли-1»), что сможет поднять широкомасштабное восстание, если ему помогут как оружием, так и подкреплением из «корпуса» Долля. Немецкие спецслужбы, поверив ему и полагаясь на доктора Долля, не зная о ликвидации республики и депортации ее автохтонного населения, решились приступить к реализации первой фазы операции «Salzsee» под кодовым названием «Римская цифра два».

23 мая 1944 г. в 2 часа 25 минут посты службы воздушного наблюдения, оповещения и связи (ВНОС) зафиксировали появление над территорией Астраханской области четырехмоторного самолета «Юнкерс-290», который, сделав большой круг по линии Приютное Элиста - Яшкуль - Николаевка - Лагань Утта, скрылся в северо-западном направлении и над другими населенными пунктами не появился. Срочно были подняты 4 «Харрикейна» 144-й истребительной авиадивизии ПВО, дислоцировавшейся в Сталинграде. Летчики, обнаружив «юнкерс» на земле в 50-60 км от селения Чилгир (к северо-востоку от него и ближе к селу Утта) и доложив командованию, пушечным огнем подожгли его. К месту посадки вражеского самолета выехали оперативные группы УНКВД Астраханской области и оперативники отдела НКВД СССР по борьбе с бандитизмом и дезертирством (ОББ НКВД СССР), находившиеся там в командировке. Так было доложено Л.П. Берии 24 мая 1944 г. начальником ОББ НКВД СССР, комиссаром госбезопасности 3-го ранга А. Леонтьевым [5, л. 50].

Д.М. Дегтев и Д.В. Зубов в своей работе предполагают, что этот самолет летел не в Калмыкию, а в Гурьевскую область Казахской ССР, куда в то время немцы активно забрасывали диверсионные группы, а группа Э. фон Шеллера вылетела из Румынии вечером 10 июня 1944 г. на самолете «Јu-290A-9» W. Nr. 0182 «A3 + AB» в составе 8 человек экипажа (командир - лейтенант Хайнрих Иенихен, радист - обер-фельдфебель Ханс Виделер) [3, с. 153-155]. Как видим, это предположение авторов противоречит имеющимся сведениям в официальных источниках. Тем более план мероприятий по делу «Арийцы», утвержденный 26 мая 1944 г., санкционировал Л.П. Берия.

Приземлившимся и обстрелянным вражеским самолетом оказался четырехмоторный «Ju-290A-9» W. Nr. 0185 «A3 + CB» из 
1-й эскадры KG200. Он вылетел из Кеннигсберга, где взял на борт 24 диверсантов из пригородной разведшколы села Валга, и сделал посадку в Румынии (аэродром Цилиштеа). В Румынии 4 диверсанта были оставлены. «Юнкерс» взлетел из аэродрома Цилиштеа, имея на борту 30 человек, в том числе 10 членов экипажа (все немцы), 20 диверсантов (18 калмыков, 1 азербайджанец и 1 осетин). Все они, разделенные на две группы, прошли подготовку в разведшколе под руководством опытного разведчика абвера гауптмана Эбергарда фон Шеллера (агентурный псевдоним Кваст), который и возглавлял эти две диверсионные группы. Э. фон Шеллер являлся сотрудником отдела «Валли-1» Управления «Абвер-Заграница», полномочия которого 14 февраля 1944 г. были переданы в РСХА. Служба «Валли-1», занимавшаяся военной и экономической разведкой, в своей деятельности контактировала с «Цеппелином» и другими органами фашистских спецслужб, действовавших на восточном фронте.

После удачного приземления Э. Шеллер распорядился направить 10 диверсантов (калмыков) в близлежащее селение Чилгир с целью добычи лошадей, а сам с остальной группой двинулся в ту же сторону. Оперативники УНКВД Астраханской области и ОББ НКВД СССР настигли диверсантов в 8 км от места посадки самолета. В результате четырехчасового боя были убиты 8 диверсантов (3 немца, 3 калмыка, осетин и азербайджанец) и 12 человек задержаны, в их числе Э. Шеллер, 6 членов экипажа (в том числе радист, оберлейтенант Ганс Ганзен). В оперативной группе УНКВД и ОББ НКВД СССР были ранены два бойца [5, л. 50-50 об.].

Плененные диверсанты были доставлены в Астрахань и там допрошены. Э. Шеллер на допросе сообщил, что он до появления советских самолетов передал в разведцентр радиограмму об успешном приземлении. Далее на следствии он показал, что заброшенным 23 мая 1944 г. двум группам было дано первыми начать операцию с установления связи с якобы имеющимися национальными повстанческими группами и в целях бесперебойной работы обеспечить безопасность главной радиостанции. Шеллер подробно изложил о снаряжении диверсантов и об общем вооружении групп, а также об ожидаемой доставке дополнительного груза самолетом 27 мая 1944 г. из Шилиштеа. Как он пояснял, каждый диверсант имел автомат с двумя дисками, 3 ручные гранаты, полное обмундирование, седло, сбрую. В общее снаряжение еще входили: 2 станковых пулемета «максим», 3 ручных пулемета, 16 винтовок. Кроме этого должны были им доставить еще около 40 тюков багажа с патронами для пулеметов, винтовок и автоматов; несколько ящиков с советскими ручными гранатами, а также медикаменты и перевязочный материал, табак и продовольствие.

На допросе Шеллер раскрыл детали цели операции. В первую очередь они должны были установить передаточный центр (реле), способный принимать сообщения агентов-радистов, подлежащих заброске в восточные области СССР, которые не могли своими маломощными передатчиками связаться непосредственно с германскими разведорганами.

Затем постепенно начать переброску подготовленных доктором Доллем 36 калмыцких эскадронов для организации и развития национального повстанческого движения в калмыцкой степи. Для этого, располагая 40-ватным передатчиком (SE90/40) с антенной, надлежало создать бесперебойную авиасвязь и необходимые условия для приема самолетов.

С надежным устройством главной станции разведорган «Валли-1» планировал начать заброску агентов в различные районы восточной России. Агенты, передавая донесения по радио на главную станцию Э. Шеллера, должны были находиться в полной уверенности, что они передают сведения непосредственно в Германию [12, с. 31].

В докладной записке А. Леонтьева на имя Л.П. Берии сообщалось, что у десантников также изъяты разные документы, штампы, печати, бланки различных учреждений и частей Красной армии. В ходе допросов были получены ценные сведения о секретной эскадpe KG200 и о месте ее дислокации. Л.П. Берия, получив полную информацию о десантниках с «Ju-290A», направил уже 26 мая служебную записку начальнику ГУКР «СМЕРШ» НКО СССР В.С. Абакумову с предложени- 
ем: «Пойманные работниками НКВД-НКГБ парашютисты представляют большой интеpec. По-видимому, немцы не знают, что калмыки высланы, но, несмотря на это, есть остатки бандитов из калмыков, с которыми немцы будут связываться. Поэтому тов. Леонтьеву всю работу сосредоточить в руках товарищей Свирина (замначальника ОББ НКВД CССР. - К. М.), Лукьянова (начальник УНКВД Астраханской области. - К. М.) и Михайлова (начальник УНКГБ Астраханской области. $-K$. M.). Тов. Мешику принять активное участие. То же надо сделать и по Гурьевской области (по всей вероятности, имелась в виду радиоигра “Тростники”. $-K . M$.). Представьте план мероприятий и регулярно докладывайте» [1, с. 173; 7, л. 93].

На основе показаний Э. фон Шеллера сотрудники ГУКР «СМЕРШ», имея опыт ведения такой радиоигры (к этому времени было проведено более ста радиоигр, а в мае 1944 г. начата 12-я) [24, с. 377, 378], подготовили план радиоигры под кодовым названием «Арийцы» и осуществляли руководство над ее проведением. Планом преследовалась цель - дезинформировать противника в таком свете, что якобы повстанческое движение в Калмыкии может вспыхнуть в любое время при определенной помощи вооружением и специалистами. Тем самым получили бы возможность захватывать забрасываемых агентов, а также грузы и самолеты противника. К радиоигре «Арийцы» были привлечены Э. фон Шеллер (Кваст), получивший псевдоним Борода, и бортрадист Ганс Ганзен под псевдонимом Колонизатор.

В радиограмме, переданной противнику в начатой радиоигре 30 мая 1944 г., сообщалось: «Посадка в 04.55 московского времени. В 12.40 атака русских истребителей. "Ю” уничтожен. Необходимое снаряжение спасли, без воды и продуктов. Гремер, Ханлапов, Беспалов, Мухин, два калмыка убиты. Лейтенант Вагнер, обер-фельдфебель Миллер, Осетров ранены. Перешли положение один, пески, район Яшкуль. Положение благоприятное, связались с партизанами, охрана обеспечена. Разведка калмыков узнала, что посадку “Ю” заметили русские. Из Сталинграда и Астрахани прислали истребителей. Ошибка “Ю” садиться днем, долго сидел, надо ночью.
Площадку готовим. До полного выяснения мною обстановки мер не принимайте. Радистом использую обер-лейтенанта Ганзена. Слушаю вас по плану. Прошу указаний. Кваст» [23, с. 199].

После первого обмена радиограммами немцы, вероятно, для проверки полученной информации от Кваста сразу же направили самолет «Ju-252» к предполагаемому месту нахождения их десанта. Самолет, облетев место высадки десанта и не получив ответ на поданные световые сигналы, под контролем отдела контрразведки СМЕРШ ПВО Южного фронта «благополучно» вернулся на свою базу. Штаб «Валли-1» радировал Квасту: «Орган поздравляет. Принимаем меры для развития операции. Исполним указания, которые ожидаем от вас. Операция в духе Римского два готовится. Когда должна начаться? Начальник органа».

В ночь с 30 на 31 мая 1944 г. появился опять «Јu-252», но уже с грузом, пробарражировав над районом предполагаемой дислокации «отряда» Кваста и не найдя его, повернул назад. Это подтвердила полученная от руководства «Валли-1» радиограмма: «“Јu-252” был ночью 30 мая у вас для помощи. Вас не нашел. Собственные имена и названия местности шифровать два раза. С этого момента только нормальные часы связи. Вскоре подбросим радистов. Всем привет. Ни пуха, ни пера. Капитан» [10, с. 65].

В ходе нескольких радиосеансов Квасту все же удалось убедить свое начальство в результативности деятельности «отряда» и возможности организовать повстанческое движение при оказании помощи оружием, боеприпасами, деньгами, продуктами. Обещанная штабом «Валли-1» помощь появилась лишь в ночь на 12 июня 1944 года. Прилетевший «Ju-290», обменявшись с «отрядом» Кваста условными сигналами, сбросил пятерых парашютистов, 20 тюков груза, а затем, сделав круг, пошел на сигнальные огни посадочной полосы. Самолет, совершив посадку в заранее подготовленную площадку-ловушку, попал колесами в ямы и в ходе перестрелки экипажа с чекистами загорелся. Правый фюзеляж с двумя двигателями, груз, в том числе 3 млн рублей, три пилота сгорели в самолете. Выбравшимся из самолета членам экипажа во время пожара и пере- 
стрелки удалось ускользнуть и трое суток скрываться в окрестностях.

Из пяти парашютистов сразу были задержаны трое: осетин Цокаев и двое татар Бацбурин и Росимов. Четвертый парашютист, Бадмаев, монгол по национальности, при приземлении разбился насмерть, а пятый, калмык, сумел скрыться.

После «пропажи» указанного самолетаподтверждением этой версии стала радиограмма Кваста в разведцентр о том, что «машина не прибыла», да и с вопросом «почему» противник насторожился, и содержание его радиограмм стало носить, скорее, проверочный характер. Несмотря на более чем двухмесячные настоятельные просьбы Кваста помочь «отряду», прислать новый самолет с необходимыми материалами, штаб «Валли-1» не дал конкретного ответа, ограничился лишь общей фразой «попытаемся прилететь с новым подвозом». Фактически на этом радиоигра стала постепенно свертываться. В последних радиограммах абверу сообщили о гибели отряда Огдонова и группы Кваста, об отказе калмыков в помощи, о бесперспективности операции [12, с. 32].

Радиоигра «Арийцы» была завершена 20 августа 1944 г., в процессе которой СМЕРШ отправил 42 радиограммы и получил из штаба «Валли-1» 23. В итоге контрразведчики СМЕРШа получили ценные сведения о сверхсекретном соединении «Люфтваффе», уничтожили два тяжелых самолета «Јu-290», в исправном состоянии были захвачены два новейших авиадвигателя. Уничтожено 12 вражеских десантников и членов экипажей самолетов, а 21 человек захвачены в плен. Были получены ценные сведения о некоторых разведшколах противника и об агентах, отправленных в глубокий тыл СССР [5, л. 17, 5050 об.; 23, с. 201].

Результаты. На этом, собственно, и завершилась операция «Salzsee», подготовленная на основе ложной информации доктора Долля о готовности калмыков восстать и с оружием в руках выступить против существующего режима, а также о каких-то мифических 36 эскадронах. Сам доктор Долль, он же Отто Рудольфович Верб, понимал, что за этот авантюризм придется ему отвечать по законам военного времени, к тому же еще руко- водство рейха явно оказалось недовольным деятельностью гиммлеровского «Цеппелина». В июле 1944 г. он тайно покидает калмыцкий легион и бесследно исчезает. Его дезертирство практически оказалось никем незамеченным, поскольку к тому времени абвер был уже расформирован, а военную разведку и контрразведку перетрясли и подчинили Главному управлению имперской безопасности.

В воспоминаниях унтерштурмфюрера СС Э. Керна, изданных еще в 1951 г., утверждается, что Отто Верб после войны под другим именем и фамилией жил и работал в восточной части Германии (ГДР) [9, с. 122-123]. По утверждению Й. Хоффманна со ссылкой на Д. Арбакова (последнего начальника штаба калмыцкого легиона) доктор Долль погиб в июле 1944 года. По свидетельству же его адъютанта Э. Батаева (чекиста Дорджиева) летом 1944 г. доктор Долль неожиданно был вызван в Берлин [1, с. 184; 22, с. 57]. Эта версия вполне вероятна, поскольку Долль, приняв решение своевременно инкогнито ретироваться, мог с целью дезинформации «доверительно» сообщить своему адъютанту о том, что его вызывает начальство в Берлин.

Что интересно, личным адъютантом, весьма доверенным человеком у зондерфюрера Долля, командира калмыцкого легиона, был внедренный чекист, советский лейтенант Эрдни Батаевич Дорджиев (по разведлегенде - Эрдни Батаевич Батаев). После загадочного исчезновения в июле 1944 г. Долля Э. Батаев и М. Хаглышев (начальник штаба), временные руководители легиона, были немцами арестованы и, по утверждению Й. Хоффманна, расстреляны. Однако немцы не успели расстрелять Батаева, и после разгрома Германии он был освобожден из концлагеря в мае 1945 года. Вскоре по возвращении на родину он был награжден орденом Красной Звезды и получил очередное звание капитана. Несмотря на заслуги, Батаев в 1949 г. по национальному признаку подвергся депортации в Узбекистан [1, с. 184; 22, с. 57].

При размышлении об идее и аргументации Долля, убедивших руководство организаций «Абвер-Заграница» и «Унтернемен Цеппелин» принять решение о проведении операции «Salzsee» («Соленое озеро»), в результате которой были потеряны два «Ju-290» с члена- 


\section{ОТЕЧЕСТВЕННАЯ ИСТОРИЯ}

ми экипажей, опытные разведчики, можно сказать, в весьма трудное время для немцев, а также о загадочном его исчезновении в период операции, проживании его после войны в восточной части Германии (ГДР), возникают непростые вопросы. Помимо этого интерес вызывает написанное Й. Хоффманном о том, что «многочисленные слухи о его (докторе Долле) личности» стали поводом «для сомнений в его личных и политических намерениях». Здесь же Хоффманн, ссылаясь на Рихтгофена, добавляет: «Идея, что д-р Долль мог быть советским агентом, совершенно чудовищна!» [22, с. 53]. Так что вполне можно согласиться с мнениями Д.М. Дегтева и Д.В. Зубова о том, что «наверняка операция "Соленое озеро” хранит в себе еще немало тайн...» $[3$, с. 159$]$ и сюрпризов.

\section{СПИСОК ЛИТЕРАТУРЫ}

1. Во имя безопасности России. - Элиста : ЗАО «Астория», 2005. - $287 \mathrm{c.}$

2. Гучинова, Э.-Б. Улица «Kalmyk Road»: история, культура и идентичность в калмыцкой общине США / Э.-Б. Гучинова. - СПб. : Алетейя, 2004. $-340 \mathrm{c}$.

3. Дегтев, Д. М. Секретные операции люфтваффе. От Гренландии до Ирака. 1939-1945 / Д. М. Дегтев, Д. В. Зубов. - М. : Центрполиграф, 2015. - 223 с.

4. Дело с докладными записками и спецсообщениями на имя руководства НКВД СССР о проделанной работе периферийными органами НКВД УНКВД по ликвидации бандитизма на территории СССР. 1943 г. // Государственный архив Российской Федерации (ГА РФ). - Ф. Р-9478. - Оп. 1. - Д. 58.

5. Дело с копиями спецсообщений, направленных ГКО и руководству НКВД СССР, о задержании вражеских парашютистов 13 июля 1941 - 31 декабря 1944 г. // ГА РФ. - Ф. Р-9478. - Оп. 1. - Д. 65.

6. Докладная на имя руководства НКВД СССР о результатах борьбы с бандитизмом и дезертирством, с уклонением от службы в Красной армии за три года Великой Отечественной войны с 1 июля 1941 по 1 июля 1944 г. // ГА РФ. Ф. Р-9478. - Оп. 1. - Д. 63.

7. Докладные записки и справки руководству НКВД и НКГБ СССР по делу следствия бывшего начальника Восточного отделения Главного управления безопасности и директора института «АТ», по борьбе с немецкими парашютистами, выброшенными и ликвидированными на территории Средней Азии, Северного Кавказа и
Закавказья в 1942-1943 гг. // ГА РФ. - Ф. Р-9478. Оп. 1. - Д. 297.

8. Зефиров, М. В. Свастика над Волгой : Люфтваффе против сталинской ПВО / М. В. Зефиров, Д. М. Дегтев, Н. Н. Баженов. - М. : АСТ : Хранитель, 2007. $-645,[1]$ с. : ил.

9. Керн, Э. Пляска смерти: Воспоминания унтерштурмфюрера СС. 1941-1945 : пер. с англ. / Э. Керн. - М. : Центрполиграф, 2007. - 255 с.

10. Лузан, Н. Контрразведка. Тайная война / Н. Лузан. - М. : ЗАО «СВР-Медиапроекты», 2014. - 224 с. : ил.

11. Максимов, К. Н. Великая Отечественная война: Калмыкия и калмыки / К. Н. Максимов ; Калмыц. ин-т гуманит. исслед. РАН; 2-е изд., доп. - М. : Наука, 2010. - 406 с.

12. Максимов, К. Н. Мифы доктора Долля / К. Н. Максимов // Военно-исторический журнал. - 2011. - Март. - № 3 (611). - С. 29-33.

13. Мюллер-Гиллебранд, Б. Сухопутная армия Германии 1933-1945 гг. : пер. с нем. / Б. МюллерГиллебранд. - М. : ЭКСМО, 2003. - 800 с.

14. Некрич, А. М. Наказанные народы / А. М. Некрич // Нева. - 1993. - № 9. - С. 223-283.

15. Нюрнбергский процесс : сб. материалов. В 8 т. Т. 3. - М. : Юрид. лит., 1989. - 656 с.

16. Органы государственной безопасности в Великой Отечественной войне : сб. документов. В 8 т. Т. 3, кн. 2 : От обороны к наступлению. 1 июля -31 декабря 1942 года. - М. : Русь, 2003. - 701 с.

17. Органы государственной безопасности в Великой Отечественной войне : сб. документов. В 8 т. Т. 4, кн. 1 : Секрет операции «Цитадель». 1 января - 30 июня 1943 года. - М. : Русь, 2008. $796 \mathrm{c}$.

18. Органы государственной безопасности в Великой Отечественной войне : сборник документов. В 8 т. Т. 4, кн. 2 : Великий перелом. 1 июля 31 декабря 1943 года. - М. : Русь, 2008. - 816 с.

19. Романько, О.В.Советский легион Гитлера. Граждане СССР в рядах вермахта и СС / О. В. Романько. - М. : Издатель Быстров, 2006. - 640 с.

20. Сводная цифровая справка о количестве состоящих на учете (с разбивкой по республикам, краям и областям) и ликвидированных бандгрупп с 1 июля 1941 по 1 января 1944 г. // ГА РФ. Ф. Р-9478. - Оп. 1. - Д. 42.

21. Советская Калмыкия. - 1971. - 3 июля (№ 135(6342)).

22. Хоффманн, Й. Немцы и калмыки. 1942-1945 / Й. Хоффманн. - Фрайбург : Ромбах, 1977. - 228 с.

23. Христофоров, В. С. «СМЕРШ»: Исторические очерки и архивные документы / В. С. Христофоров, В. К. Виноградов, О. К. Матвеев. - М. : Главархив Москвы ; Московские учебники и Картолитография, 2003. -343 с. 
24. Чайковский, А. С. НКВД и СМЕРШ против Абвера и РСХА / А. С. Чайковский. - М. : Алгоритм, 2016. $-592 \mathrm{c}$.

25. Чекисты в Сталинградской битве: Документы, воспоминания, очерки. - Волгоград : Издатель, 2002. $-432 \mathrm{c}$.

26. Чуев, С. Проклятые солдаты / С. Чуев. -М. : Эксмо : Яуза, 2004. - 576 с., ил.

27. Ямпольский, В. П. «... Уничтожить Россию весной 1941 г.» (А. Гитлер, 31 июля 1940 года): документы спецслужб СССР и Германии / В. П. Ямпольский. 1937-1945 гг. - М. : Кучково поле, 2008. -656 с.

\section{REFERENCES}

1. Vo imya bezopasnosti Rossii [In the Name of Russia's Security]. Elista, Astoriya Publ., 2005. 287 p.

2. Guchinova E.B. Ulitsa «Kalmyk Road»: istoriya, kultura i identichnost $v$ kalmytskoy obshchine SShA [Kalmyk Road Street: History, Culture and Identity in the Kalmyk Community of the USA]. Saint Petersburg, Aleteya Publ., 2004. 340 p.

3. Degtev D.M., Zubov D.V. Sekretnye operatsii lyuftvaffe. Ot Grenlandii do Iraka. $1939-$ 1945 [The Secret Operations of Luftwaffe. From Greenland to Iraq. 1939-1945]. Moscow, Tsentrpoligraf Publ., 2015. 223 p.

4. Delo s dokladnymi zapiskami i spetssoobshcheniyami na imya rukovodstva NKVD SSSR o prodelannoy rabote periferiynymi organami NKVD UNKVD po likvidatsii banditizma na territorii SSSR. 1943 g. [A Folder Containing Internal Memorandums and Special Reports Addressed to Top-Ranking NKVD Officers on the Scope of Work Conducted by Peripheral NKVD Agencies for the Elimination of Banditism in the Territory of the USSR]. Gosudarstvennyy arkhiv Rossiyskoy Federatsii [State Archive of the Russian Federation], F. P-9478, Op. 1, D. 58.

5. Delo s kopiyami spetssoobshcheniy, napravlennykh GKO i rukovodstvu NKVD SSSR o zaderzhanii vrazheskikh parashyutistov 13 iyulya 1941 - 31 dekabrya 1944 g. [A Folder Containing Special Reports Addressed to the State Defense Committee of the USSR and Top-Ranking NKVD Officers on Detention of Enemy Paratroopers in the Period13 July 1943 - 31 December 1944]. Gosudarstvennyy arkhiv Rossiyskoy Federatsii [State Archive of the Russian Federation], F. R-9478, Op. 1, D. 65.

6. Dokladnaya na imya rukovodstva NKVD SSSR o rezultatakh borby $\mathrm{s}$ banditizmom $\mathrm{i}$ dezertirstvom, s ukloneniem ot sluzhby v Krasnoy armii za tri goda Velikoy Otechestvennoy voyny s 1 iyulya 1941 po 1 iyulya 1944 g. [An Internal Memorandum Addressed to Top-Ranking NKVD Officers on the Results of Struggle Against Banditism and Defection,
Evasion of Military Service in the Red Army during the Three Years of the Great Patriotic War: from 1 July 1941 to 1 July 1944]. Gosudarstvennyy arkhiv Rossiyskoy Federatsii [State Archive of the Russian Federation], F. R-9478, Op. 1, D. 63.

7. Dokladnye zapiski i spravki rukovodstvu NKVD i NKGB SSSR po delu sledstviya byvshego nachalnika Vostochnogo otdeleniya Glavnogo upravleniya bezopasnosti i direktora instituta «AT», po borbe $\mathrm{s}$ nemetskimi parashyutistami, vybroshennymi i likvidirovannymi na territorii Sredney Azii, Severnogo Kavkaza i Zakavkaz'ya v 1942-1943 gg. [Internal Memorandums and Reports Addressed to the Top-Ranking USSR NKVD and NKGB Officers on the Case of an Ex-Chief of the Eastern Division of the Main Security Department and a Director of AT Institute Regarding the Struggle Against German Paratroopers Dropped and Eliminated in the Territories of Central Asia, the North Caucasus and the Transcaucasia in 1942-1944]. Gosudarstvennyy arkhiv Rossiyskoy Federatsii [State Archive of the Russian Federation], F. R-9478, Op. 1, D. 297.

8. Zefirov M.V., Degtev D.M., Bazhenov N.N. Svastika nad Volgoy. Lyuftvaffe protiv stalinskoy PVO [Swastika on the Volga. Luftwaffe against the Stalinist Air Defense]. Moscow, AST Publ.; KHRANITEL Publ., 2007. 645, [1]p.

9. Kern E. Plyaska smerti: Vospominaniya untershturmfyurera SS. 1941-1945 [Dance of Death: Memories of the SS Untersturmfbhrer. 1941-1945]. Moscow, Tsentrpoligraf Publ., 2007. 255 p.

10. Luzan N. Kontrrazvedka. Taynaya voyna [Counter-Intelligence. Secret War]. Moscow, SVRMediaproekty Publ., 2014. 224 p.

11. Maksimov K.N. Velikaya Otechestvennaya voyna: Kalmykiya i kalmyki [The Great Patriotic War: Kalmykia and the Kalmyks]. Moscow, Nauka Publ., 2010. 406 p.

12. Maksimov K.N. Mify doktora Dollya [Myths of Dr. Doll]. Voenno-istoricheskiy zhurnal [Military History Journal], 2011, no. 3 (611), pp. 29-33.

13. Mueller-Hillebrand B. Sukhoputnaya armiya Germanii 1933-1945 gg. [Land Army in Germany in 1933-1945]. Moscow, EKSMO Publ., 2003. 800 p.

14. Nekrich A.M. Nakazannye narody [The Punished Peoples]. Neva, 1993, no. 9, pp. 223-283.

15. Nyurnbergskiy protsess: sb. materialov. $V 8 t$. T. 3. [The Nuremberg Trials: the Collection of Materials. In 8 vols. Vol. 3]. Moscow, Yurid. lit. Publ., 1989. 656 p.

16. Organy gosudarstvennoy bezopasnosti $v$ Velikoy Otechestvennoy voyne : sb. dokumentov. V8t. T. 3, kn. 2. Ot oborony $k$ nastupleniyu. 1 iyulya 31 dekabrya 1942 goda [Bodies of State Security in the Great Patriotic War: Collection of Documents. In 8 vols. Vol. 3. Book 2: From Defense to Attack. 1 July 31 December 1942]. Moscow, Rus Publ., 2003. 701 p. 
17. Organy gosudarstvennoy bezopasnosti v Velikoy Otechestvennoy voyne: sb. dokumentov. $V 8 t$. T. 4, kn. 1. Sekret operatsii «Tsitadel». 1 yanvarya30 iyunya 1943 goda [Bodies of State Security in the Great Patriotic War: Collection of Documents. In 8 vols. Vol. 4. Book 1. The Secret of the Tsitadel Operation. 1 January-30 June 1943]. Moscow, Rus Publ., 2008. $796 \mathrm{p}$.

18. Organy gosudarstvennoy bezopasnosti v Velikoy Otechestvennoy voyne : sbornik dokumentov. V 8 t. T. 4, kn. 2.Velikiy perelom. 1 iyulya 31 dekabrya 1943 goda [Bodies of State Security in the Great Patriotic War: Collection of Documents. In 8 vols. Vol. 4. Book 2. A Great Turning Point. 1 July31 December 1943]. Moscow, Rus Publ., 2008. 816 p.

19. Romanko O.V. Sovetskiy legion Gitlera. Grazhdane SSSR v ryadakh vermakhta i SS [Soviet Legion of Hitler. Soviet Citizens in the Ranks of the Wehrmacht and SS]. Moscow, Bystrov Publ., 2006. 640 p.

20. Svodnaya tsifrovaya spravka o kolichestve sostoyashchikh na uchete (s razbivkoy po respublikam, krayam i oblastyam) i likvidirovannykh bandgrupp s 1 iyulya 1941 po 1 yanvarya 1944 g. [A Reference Digital Report on the Number of Registered (Catalogued by Republics, Krais and Oblasts) and Eliminated Criminal Gangs: from 1 July 1941 to 1 January 1944]. Gosudarstvennyy arkhiv Rossiyskoy Federatsii [State Archive of the Russian Federation], F. P-9478, Op. 1, D. 42.
21. Sovetskaya Kalmykiya [Soviet Kalmykia], 1971, no. 135 (6342), July 3.

22. Hoffmann Y. Nemtsy i kalmyki. 1942-1945 [Germans and Kalmyks. 1942-1945]. Freiburg, Rombach, 1977. 228 p.

23. Khristoforov V.S., Vinogradov V.K., Matveev O.K. «SMERSH»: Istoricheskie ocherki $i$ arkhivnye dokumenty [SMERSH: Historical Essays and Archival Documents]. Moscow, Izd-vo Glavarkhiv Moskvy, $2003.343 \mathrm{p}$.

24. Chaykovskiy A. S. NKVD i SMERSH protiv Abvera $i$ RSKHA [NKVD and SMERSH against the Abwehr and the RSHA]. Moscow, Algoritm Publ., 2016. 592 p.

25. Chekisty v Stalingradskoy bitve: Dokumenty, vospominaniya, ocherki [Chekists in the Battle for Stalingrad: Documents, Memories, Essays]. Volgograd, Izdatel Publ., 2002. 432 p.

26. Chuev S. Proklyatye soldaty [Damned Soldiers]. Moscow, Eksmo Publ.; Yauza Publ., 2004. $576 \mathrm{p}$.

27. Yampolskiy V.P. «...Unichtozhit Rossiyu vesnoy 1941 g.» (A. Gitler, 31 iyulya 1940 goda): dokumenty spetssluzhb SSSR $i$ Germanii [“... to Destroy Russia in the Spring of 1941" (A. Hitler, July 31, 1940): Documents of the Special Services of the USSR and Germany. 1937-1945]. Moscow, Kuchkovo pole Publ., 2008. 656 p.

\section{Information about the Author}

Konstantin N. Maksimov, Doctor of Sciences (History), Professor, Kalmyk State University named after B.B. Gorodovikov, Puschkina St., 11, 358000 Elista, Russian Federation, tsagadam@mail.ru, https://orcid.org/0000-0002-9475-6137

\section{Информация об авторе}

Константин Николаевич Максимов, доктор исторических наук, профессор, Калмыцкий государственный университет им. Б.Б. Городовикова, ул. Пушкина, 11, 358000 г. Элиста, Российская Федерация, tsagadam@mail.ru, https://orcid.org/0000-0002-9475-6137 